\title{
Research Article \\ ISOLATION AND IDENTIFICATION OF METHICILLIN RESISTANT STAPHYLOCOCCI FROM MILK SAMPLES WITH BOVINE MASTITIS AND THEIR DRUG RESISTANCE PATTERNS IN AND AROUND JUNAGADH, GUJARAT
}

\author{
JIVANI H.M. ${ }^{*}$, MATHAPATI B.S., JAVIA B.B., KALARIYA V.A., SHAH T.M., NIMAVAT V.R., BARAD D.B. AND GHODASARA S.N. \\ Department of Veterinary Microbiology, College of Veterinary Science and Animal Husbandry, Junagadh Agricultural University, Junagadh 362001, Gujarat, India \\ *Corresponding Author: Email-hetaljivani33@gmail.com
}

Received: August 09, 2017; Revised: March 27, 2018; Accepted: March 28, 2018; Published: March 30, 2018

\begin{abstract}
Aim: The study was carried out with aim to isolate methicillin resistant staphylococci from milk samples and determine antibiogram pattern of methcillin resistant staphylococcal isolates. Materials and Methods: A total of 50 milk samples were collected aseptically from different places in and around Junagadh city. Which were subjected to cultural isolation and biochemical characterization with routine and MRSA specific media, Kirby-Bauer disk diffusion method were utilized for antibiogram. Results: Results showed that out of total 50 samples, 7 isolates (14\%) were found to be MRS. The MRS isolates showed highest sensitivity towards chloramphenicol (100\%), gentamicin (85.71\%), ampicillin/sulbactam (71.42\%), oxytetracyline (71.42\%), levofloxacin, enrofloxacin and ceftriaxone (57.14 \%). The pattern clearly indicated that the overall high percent of MRS isolates were resistant to penicillin-G (100\%), methicillin (100\%), amoxicillin/sulbactam (100 \%) followed by cefotaxime/clavulanic acid $(85.71 \%)$, amoxyclav $(71.42 \%)$, ceftriaxone/sulbactam and cefoperazone/sulbactam (57.14 \%). Conclusions: Staphylococcus spp. was found to be the major cause of bovine mastitis in this geographical region and methicillin resistant isolates from milk was showing multidrug resistant.
\end{abstract}

Keywords- Antibiogram pattern, Bovine mastitis, MRS.

Citation: Jivani H.M., et al., (2018) Isolation and Identification of Methicillin Resistant Staphylococci from Milk Samples with Bovine Mastitis and Their Drug Resistance Patterns in and Around Junagadh, Gujarat. International Journal of Microbiology Research, ISSN: 0975-5276 \& E-ISSN: 0975-9174, Volume 10, Issue 3, pp.-1094-1096.

Copyright: Copyright@2018 Jivani H.M., et al., This is an open-access article distributed under the terms of the Creative Commons Attribution License, which permits unrestricted use, distribution and reproduction in any medium, provided the original author and source are credited.

Academic Editor / Reviewer: Mahajan V., Dr Rahul Singh Arya, Dr Rout

\section{Introduction}

Milk, is an essential nutritious diet to young mammals containing proteins, lipids, amino acids, vitamins, minerals and carbohydrates. Milk also serves as an optimum medium for the propagation of various pathogenic and spoilage microorganisms [1-2]. These pathogens invade the mammary glands, develop and multiply, producing some toxic substances that results in inflammation, reduced milk production and altered milk quality, leading to a clinical condition known as mastitis [3-4]. and it is always multietiological disease characterized with or without physical, chemical and bacteriological quality of milk due to pathological changes in mammary tissue [5-6]. Due to the involvement of multiple etiological agents it always remained a challenge to veterinarian all over the globe [7]. Mastitis pathogens can be divided into contagious and environmental. The primary reservoir of contagious pathogens is an infected udder whereas a contaminated environment is the primary reservoir of pathogens causing environmental mastitis. Staphylococcus aureus subsp. aureus, Streptococcus agalactiae and Mycoplasma spp. are considered as typical contagious pathogens. Among the wide spectrum of bacterial mastitis pathogens, Staphylococcus aureus is recognized as the most frequent isolate from clinical and subclinical bovine mastitis [8]. It has overcome most of the therapeutic agents that have been developed in the recent years and hence the antimicrobial chemotherapy for this species has always been empirical. The most notable example of this phenomenon was the emergence of methicillin resistant staphylococci and appearance of MRS in milk and dairy foods has become a major concern for animal and human health. Therefore, the aim of the study was to determine the antimicrobial resistance of MRS isolates from clinical and subclinical cases of bovine mastitis in Junagadh.

\section{Materials and Methods}

Sample collection: A total of 50 milk samples were collected from different places in and around Junagadh city. The samples were collected in sterilized milk collecting tubes and transported to laboratory of the Department of Veterinary Microbiology, College of Veterinary Science \& Animal Husbandry, JAU, Juangadh for further processing and microbiological analysis.

Isolation and Identification of methicillin resistant staphylococci:

The selective medium used for isolation of MRS was Hichrom MeReSa Agar (HiMedia Pvt. Ltd.). A loopful of inoculum were streaked on MeReSa agar and incubated for 48 hours at $37^{\circ} \mathrm{C}$. Characteristic appearances of bluish-green colonies were considered to be presumptive MRS. [Fig-1]. The pure cultures were streaked on Nutrient agar (HiMedia Pvt. Ltd.) and incubated for 24 hours at $37^{\circ} \mathrm{C}$ and were further characterized by biochemical tests.

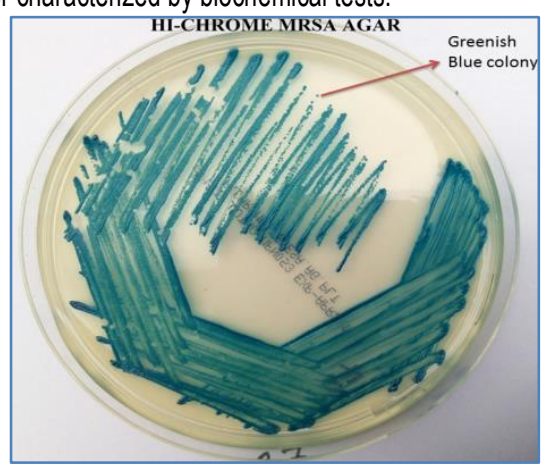

Fig-1 Colonies of methicillin resistant staphylococci on HichromMeReSa Agar showing typical bluish-green colonies 


\section{Morphological characteristics:}

The smear was prepared from the isolated culture on clean grease free microscopic glass slide and stained with Gram's Method of staining. The stained smear was observed under microscope. Smear revealed Gram positive, spherical cells arranged in irregular clusters resembling to bunch of grapes.

Table-1 Morphological and culture characteristics of methicillin resistant staphylococci

\begin{tabular}{|l|l|l|}
\hline \multicolumn{1}{|c|}{ Isolated bacteria } & \multicolumn{1}{|c|}{ Gram staining } & \multicolumn{1}{c|}{$\begin{array}{c}\text { Culture characteristics } \\
\text { on selective media }\end{array}$} \\
\hline $\begin{array}{l}\text { Methicillin resistant } \\
\text { staphylococci }\end{array}$ & $\begin{array}{l}\text { Gram positive cocci (in } \\
\text { clusters) }\end{array}$ & Bluish-green colonies \\
\hline
\end{tabular}

Biochemical examination: Biochemical tests were performed to confirm MRS using catalase test, coagulase test, oxidase test and mannitol fermentation.

Table-2 Biochemical characterization of methicillin resistant staphylococci

\begin{tabular}{|l|c|}
\hline \multicolumn{1}{|c|}{ Biochemical test } & Reaction \\
\hline Catalase test & Positive \\
\hline $\begin{array}{l}\text { Tube Coagulase } \\
\text { test }\end{array}$ & Positive \\
\hline Oxidase test & Negative \\
\hline $\begin{array}{l}\text { Mannitol } \\
\text { fermentation }\end{array}$ & Positive \\
\hline
\end{tabular}

\section{Antibiogram pattern of the isolated MRS}

All the isolates obtained were subjected to in vitro antibiotic sensitivity test as per disc diffusion method [9]. With the help of a platinum loop, a small amount of test culture was transferred into a tube of brain heart infusion broth and incubated for $2-5 \mathrm{~h}$ at $37^{\circ} \mathrm{C}$, so as to obtain turbidity. With the help of a sterile cotton swab, the broth culture was then evenly spread by smearing over the surface of MuellerHinton agar plates. The antimicrobial discs were placed on the agar and gently pressed. These were then, incubated at $37^{\circ} \mathrm{C}$ for $24 \mathrm{~h}$. The sensitivity was observed on the basis of zone size interpretation chart, provided by the manufacturer. The results were recorded as sensitive, inter- mediate and resistant. Different antimicrobials used were amoxicillin/sulbactam (30/15mcg), amoxyclav (30 mcg), ampicillin/sulbactam $(20 \mathrm{mcg})$, cefoperazone/sulbactam $(75 / 30 \mathrm{mcg})$, cefotaxime/clavulanic acid $(30 / 10 \mathrm{mcg})$, ceftriaxone $(30 \mathrm{mcg})$, ceftriaxone sulbactam $(30 / 15 \mathrm{mcg})$, chloramphenicol $(30 \mathrm{mcg})$, enrofloxacin $(10 \mathrm{mcg})$, gentamicin $(20 \mathrm{mcg})$, levofloxacin $(5 \mathrm{mcg})$, methicillin $(5 \mathrm{mcg})$, oxytetracycline (30mcg), penicillin-G (10 units)(Hi media).

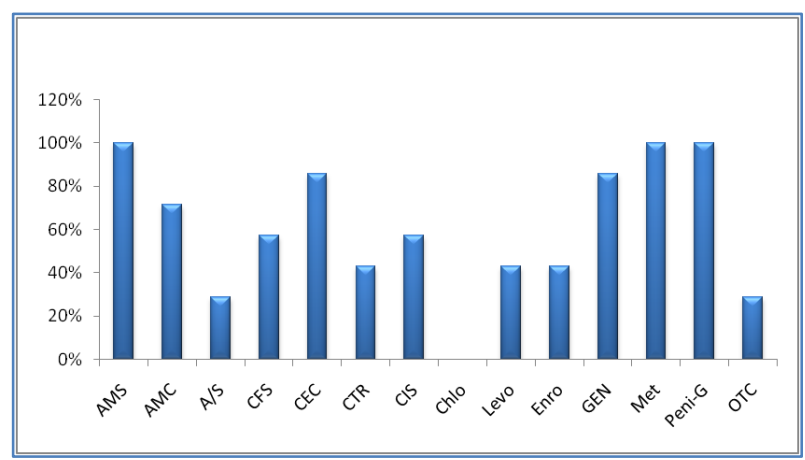

Fig-2 Antibiogram of methicillin resistant staphylococci isolates

\section{Results}

Analysis of result showed that out of total 50 samples of milk resulted in the isolation of 7 isolates (14\%) of MRS according to morphological and cultural characteristics [Table-1] and biochemical tests [Table-2]. In the present study, MRS isolates were found variably resistant to the antibiotics tested. The MRS isolates showed highest sensitivity towards chloramphenicol (100\%), gentamicin (85.71\%), ampicillin/sulbactam (71.42\%), oxytetracyline (71.42\%), levofloxacin, enrofloxacin and ceftriaxone $(57.14 \%)$. The pattern clearly indicated that the overall high percent of MRS isolates were resistant to penicillin-G (100\%), methicillin $(100 \%)$ amoxicillin/sulbactam (100 \%) followed by cefotaxime/clavulanic acid $(85.71 \%)$, amoxyclav $(71.42 \%)$, ceftriaxone/sulbactam and cefoperazonel sulbactam (57.14 \%) [Fig-2].

\section{Discussion}

This study was designed to determine the prevalence of MRS isolates among staphylococcal isolates and antimicrobial susceptibility of these isolates. Accurate and early determination of methicillin resistance is of key importance in the prognosis of infections caused by staphylococci. The sensitivity and specificity values of the phenotypic methods used for determination of MRS are known to vary depending on the media used for inoculation, the $\mathrm{NaCl}$ concentration, the incubation temperature and time, and the experience of the personnel examining the plates. Large number of generally Gram positive bacteria such as Staphylococcus and Streptococcus spp. may be present in milk when it leaves the udder [10]. Of the 50 milk samples, 7 (14\%) were found to be positive for MRS. The prevalence of MRS might be location specific and antibiotic usage pattern dependent as various observations reported in different regions. The occurrence of MRS has been shown 2.8 and $4.5 \%$ in different studies on Korean herds [11. 12]. In herds of France and Belgium, it was shown 3.2 and $9.3 \%$ of tested strains [13-14], 17.2\% MRS in Aydin region of Turkey [15]. In Switzerland and Germany, only $0.2 \%$ of MRS has been reported [16]. Antibiotic resistance development among the bacteria poses a problem of concern. Effectiveness of current treatments and ability to control infectious diseases in animals may become hazardous.

\section{Conclusions}

The evolution of antibiotic resistance in S.aureus strains is a serious cause of concern in dairy animals. Total 50 milk samples from in and around Junagadh district were screened for mastitis by various conventional microbiological methods. The antibiotic resistance pattern shown by bovine isolates was observed to be different, indicating different usage pattern in human and veterinary practice. Strains of staphylococci resistant to beta-lactam antibiotics in intra-mammary dissemination often produce incurable severe intra-herd infections. All methicillin resistant isolate from milk having multidrug resistant. There is a need for adequate policy framework on infection control that will reflect the current realities on the epidemiologic characters of MRS. Strict implementation of control program to checkmate the spread of MRS infections is very much necessary Epidemiological studies on the spread of MRS infections at the local, national and international levels will help in designing strategies for preventing the spread.

Application of research: This research has produced very important epidemiological data about MRS which is base for further research in this zone that is in and around Junagadh, Gujarat, India

Research Category: Veterinary Science

Abbreviations:

MRS=Methicillin resistant Staphylococci

Acknowledgement / Funding: Author thankful to College of Veterinary Science and Animal Husbandry, Junagadh Agricultural University, Junagadh 362001, Gujarat

\section{*Research Guide or Chairperson of research: Dr B. S. Mathapati}

University: Junagadh Agricultural University, Junagadh 362001, Gujarat

Research project name or number: MVSc Thesis -Project-Optimization of real time pcr for detection of methicillin resistant staphylococci and molecular characterization of mecAgene 


\section{Author Contributions: All author equally contributed}

Author statement: All authors read, reviewed, agree and approved the final manuscript

\section{Conflict of Interest: None declared}

Ethical approval: This article does not contain any studies with human participants or animals performed by any of the authors.

\section{References}

[1] Minst K., Martibauer E., Miller T. and Meyer C. (2012) J. Dairy Sci., 95, 6957-6962.

[2] Gatti M., Bottari B., Lazzi C., Neviani E. and Mucchetti G. (2013) J. Dairy Sci., 97, 573-591.

[3] Oliver S. P. and Muranda S. E. (2012) Vet. Clin. Food Anim., 28, 165-185.

[4] Rall V.L. M., Miranda E. S., Castilho I. G. and Camargo C. H. (2013) J. Dairy Sci., 97, 829-837.

[5] Viguier C., Arora S., Gilmartin N., Welbeck K. and O'Kennedy R. (2009) Trends Biotechnol., 27, 486-493.

[6] Gunther J., Esch K., Poschadel N., Petzl W., Zerbe H., Mitterhuemer S., Blum H. and Seyfert H. M. (2011) Infect Immun., 79, 695-707.

[7] Vashney S., Vashney P., Dash S. K., Gupta M. K., Kumar A., Singh B. and Sharma A. (2012) Med. Plants, 4, 167-169.

[8] Taponen S., Simojoki H., Haveri M., Larsen H. D. and Pyorala S. (2006) Vet Microbiology, 115, 199-207.

[9] Bauer A. W., Kirby W.W.M., Sherris J. C. and Turck M. (1966) Am. J. Clin. Pathol., 45, 493.

[10] Holm C. and Jespersen L. (2003) Appl. and Environ. Microbiol., 69, 28572863.

[11] Lee J. H. (2003) Appl. Environ. Microbiol., 69(11), 6489-6494.

[12] Moon J. S., Lee A. R., Kang H. M., Lee E. S., Kim M. N., Paik Y. H., Park Y. H., JooY. S. and Koo H. C. (2007) J. Dairy Sci., 90(3), 1176-1185.

[13] Alves P. D., McCulloch J. A., Even S., Le Marechal C., Thierry A., Grosset N., Azevedo V., Rosa C. A., Vautor E. and Loir Y. (2009) Vet. Microbiol., 137(1-2), 190-195.

[14] Vanderhaeghen W., Cerpentier T., Adriaensen C., Vicca J., Hermans K. and Butaye P. (2010) Vet. Microbiol., 144(1-2), 166-171.

[15] Turkyilmaz S., Tekbiyik S., Oryasin E. and Bozdogan B. (2010) Zoonoses Public Health., 57(3), 197-203.

[16] Monecke S., Kuhnert P., Hotzel H., Slickers P. and Ehricht R. (2007) Vet. Microbiol. 125(1-2), 128-140. 